\title{
COVID-19 Pandemic: What is Known Till June 2020 and What is Yet to Know? \\ Piryani RM, ${ }^{1}$ Piryani $S,{ }^{2}$ Piryani $S,{ }^{3}$ Dangal $G,{ }^{4}$ Shah JN ${ }^{5}$
}

${ }^{1}$ Department of Internal Medicine, Universal College of Medical Sciences, Bhairahawa, Nepal.

${ }^{2}$ Public Health Consultant, Karachi, Pakistan.

${ }^{3}$ Department of Radiology, Memon Hospital, Karachi, Pakistan.

${ }^{4}$ Department of Obstetrics and Gynecology, Kathmandu Model Hospital, Nepal.

${ }^{5}$ Department of Surgery, Patan Academy of Health Sciences, Lalitpur, Nepal.

\section{Corresponding Author}

Rano Mal Piryani

Department of Internal Medicine,

Universal College of Medical Sciences,

Bhairahawa, Nepal.

E-mail: rano.piryani@gmail.com

Citation

Piryani RM, Piryani S, Piryani S, Dangal G, Shah JN. COVID-19 Pandemic: What is Known Till June 2020 and What is Yet to Know? Kathmandu Univ Med J. 2020;COVID-19 Special Issue 70(2):90-3.

\begin{abstract}
Since first cluster of unknown pneumonia from China reported in December 2019 to World Health Organization, more than 10.5 million new cases and more than 0.513 million deaths have been reported till June 30, 2020 in six months' time. World got to know lot of facts about COVID-19 within short period of six months and success stories too concerning its containment. The situation has constantly been unfolding every moment educating people regarding public health and clinical aspects of the infection and disease and its impact on countries and communities. But still lot of information and evidences are required with regard to pharmacological interventions including effective drugs and efficacious vaccine to mitigate the impact of COVID-19 pandemic at all levels. It seems that we have to live with COVID-19 months-years as the virus is going to stay for longer period of time. The option is to continue practice of effective non-pharmacological interventions as to minimize spread of COVID-19 and ensure adequate provision of PPE to healthcare workforce and testing of health-care workers (HCWs) as to alleviate the anxiety of $\mathrm{HCW}$ and lessen their depletion by unnecessary quarantine thereby protect their health and reduce in hospital transmission.
\end{abstract}

\section{KEY WORDS}

COVID-19, Facts, Interventions, Pandemic

\section{INTRODUCTION}

COVID-19 is an acute highly contagious infectious disease primarily involving respiratory system caused by coronavirus SARS-CoV-2. It was first detected in Wuhan, Hubei province of China, in December 2019. ${ }^{1}$ World Health Organization declared COVID-19 a global pandemic on March 11, 2020. ${ }^{2}$

\section{Global Situation}

COVID-19 is affecting 213 countries and territories around the world and 2 international conveyances. As of June 30, 2020 , total number of new cases reported are $10,566,649$, deaths 513,222, recovered 5,825,876, and currently infected patients $4,188,397$. $^{3}$

The global death percentage is around $4.86 \%$ but there are differences in countries with respect to level of epidemic (number of new cases and mortality), population density, response of people living in these countries and containment strategies. ${ }^{3,4}$
Table 1. Month-wise reported new cases, deaths and death percentage globally.

\begin{tabular}{|llll|}
\hline Month & New cases & Death & $\begin{array}{l}\text { Death } \\
\text { Percentage }\end{array}$ \\
\hline January & 11,950 & 259 & 2.16 \\
\hline February & 74,656 & 2718 & 3.64 \\
\hline March & 775,880 & 41249 & 5.31 \\
\hline April & $2,393,224$ & 191070 & 7.98 \\
\hline May & $2,984,142$ & 142,532 & 4.77 \\
\hline June & $4,326,797$ & 135,394 & 3.13 \\
\hline Total & $10,566,649$ & 513,222 & 4.86 \\
\hline
\end{tabular}

\section{Situation in South Asia}

More than 60 thousand new cases and more around 18 hundred deaths are reported in 8 South Asian Association of Regional Countries (SAARC) as of May 01, 2020 (00.42 GMT).$^{3}$ 
Table 2. COVID-19 Status of SAARC Countries June 30, 2020.

\begin{tabular}{|c|c|c|c|c|c|c|}
\hline Country & Total Cases & Total Deaths & Death Percent & Total Recovered & Recovery Rate & Total Active \\
\hline India & 585,792 & 17,410 & $2.97 \%$ & 347,836 & $59.4 \%$ & 220,546 \\
\hline Pakistan & 209,557 & 4,304 & $2.05 \%$ & 98,723 & $47.1 \%$ & 106,530 \\
\hline Bangladesh & 145,483 & 1,847 & $1.27 \%$ & 59,624 & $41.0 \%$ & 84,012 \\
\hline Afghanistan & 31,517 & 746 & $2.37 \%$ & 14,131 & $44.8 \%$ & 16,640 \\
\hline Nepal & 13,564 & 29 & $0.21 \%$ & 3,194 & $23.5 \%$ & 10,341 \\
\hline Maldives & 2,361 & 9 & $0.38 \%$ & 1,944 & $82.3 \%$ & 408 \\
\hline Sri Lanka & 2,047 & 11 & $0.54 \%$ & 1,711 & $83.6 \%$ & 325 \\
\hline Bhutan & 77 & 0 & $0 \%$ & 44 & $57.1 \%$ & 33 \\
\hline Total & 990,398 & 24,356 & $2.46 \%$ & 527,207 & $53.2 \%$ & 438,835 \\
\hline
\end{tabular}

SAARC countries' death percentage is around $2.5 \%$ but there is little bit variation in countries with respect to mortality, population density, response of people living in these countries and containment strategies. ${ }^{3}$

\section{Magnitude of risk}

In order to assess the magnitude of the risk posed by COVID-19, three parameters need to be understood; transmission rate (number of newly infected people from a single case), case fatality rate (percent of cases that result in death) and possibility of asymptomatic case transmission. ${ }^{3}$

The initial studies had estimated Ro (reproductive number) between 1.5 and 3.5..$^{5-7}$ On January 23, 2020, WHO revealed its estimated Ro between 1.4 and $2.5 .^{8}$ It is said that an outbreak with a reproductive number of below 1 will gradually disappear. ${ }^{3}$

An earlier estimate had put the fatality rate $3 \%$ but as per epidemiologists' opinion fatality rate can change if virus can mutate. For comparison, the case fatality rate for SARS was $10 \%$, and for MERS 34\%., ${ }^{3,9}$ Seasonal flu generally kills far fewer than $1 \%$ of those infected. ${ }^{3,10}$ Current data suggest that case fatality risk is around $1 \%$ putting somewhere in between 1957 influenza pandemic (0.6\%) and 1918 Spanish influenza pandemic (2\%). The risk is more than Seasonal flu. ${ }^{11}$

\section{Box 1. What is known}

The level of epidemic/outbreak in different countries (number of new cases, deaths, patients recovered), containment and mitigation strategies and response of public. ${ }^{3}$

The genome sequences of SARS-CoV- 2 is evident. ${ }^{14}$

An infected person on an average spreads the disease 2-3 persons, an exponential rate of growth. ${ }^{11}$

The disease primarily affects respiratory tract but can involve other organs of the body too. ${ }^{15}$

Clinical courses range from asymptomatic patient to very mild disease, may progress to severe disease with pneumonia and some patients develop critical disease. Around $80 \%$ have mild disease, $15 \%$ moderate-severe and $5 \%$ critical disease. ${ }^{15,16}$

There are sufficient number of asymptomatic cases. As per studies between $5 \%$ and $80 \%$ cases may be asymptomatic; some asymptomatic cases will become symptomatic over one week labelled as pre-symptomatic. Asymptomatic and patient in pre-symptomatic stage can infect the people. ${ }^{17-19}$
COID-19 spreads rapidly in large gatherings. In this context World Health Organization has issued interim guidance on April 2020 Practical consideration and recommendations for religious leaders and faith-based communities in the context of COVID-19. ${ }^{20}$

The mild cases which are around $80 \%$ of all new cases can be treated at home provided adequately isolated otherwise in the isolation facilities of hospital..$^{21,22}$

Approximately 15 per cent of COVID-19 patients are categorized as 'severe' and require high flow oxygen therapy. This may help in early recovery. ${ }^{23}$

Most of the critical patients do not require ventilators as basic problem is in the capillaries rather than in the alveoli of lungs. There are more deaths reported in ventilated patients. ${ }^{24,25}$

The hospitals are/ can be the sources of spread if adequate personal protective equipment (PPE) are not provided to healthcare workforce and testing of healthcare workforce is not done. ${ }^{26-28}$

Real-time reverse transcription-polymerase chain reaction (RT-PCR) test is the only reliable test available at this point in time for diagnosis of COVID-19, but this can be negative in $33 \%$ of cases and rapid tests are not meant for the acute and accurate diagnosis. ${ }^{29}$

Rapid tests (immunoassays) have been developed detecting antigen or IgM and IgG antibodies. Rapid antigen test has poor sensitivity. IgM is detected after seven days of infection indicating recent infection; these antibodies are short-lived. While IgG remains in the serum but for how long? and its protective effect is yet to be known. ${ }^{29}$

The importance of social distancing, wearing mask, hand hygiene, respiratory hygiene and cough etiquettes in reducing the transmission and spread of infection is very well recognized. $4,22,30$

The significance of lockdown is to flatten the curve and provide time to healthcare workforce to strategize containment and mitigation plan provided implementation of additional non-pharmacological interventions continue during lockdown period. Howevver, the long-term lockdown compromises care of patient with other disease/s, limits livelihood, negative impact on economy, etc. There is worth of selective lockdown in limited area and isolation of elderly and patients with comorbidities. ${ }^{31-34}$

There are no data from controlled clinical trial and no high-quality evidence are available to support the use of any medication to treat the COVID-19 patient. Various drugs in different combination in different parts of country in different countries are continuously being used since the outbreak begins. The literature is available for interpretation. $^{34}$

World Health Organization has initiated "Solidarity Drug Trial" with voluntary participation of the countries in trial. ${ }^{35}$

Convalescent plasma of recovered COVID-19 patient has also been used for passive immunization as a treatment. ${ }^{36}$

Some vaccines are under third stage of trial. As per WHO landscape documents there are 70 coronavirus vaccines in various process of development; three are being tested in human trials. ${ }^{37,38}$ 
Various practical models for containment of COVID-19 at country level and local level with positive impact are available to learn and apply with modification/adjustment at other places. $^{39}$

Mainstream of the healthcare workforce understand the facts, involved in dealing pandemic and exposed at various level but they are anxious due to short supply of PPE and loss of their colleagues while caring COVID-19 patients. Their physical and mental wellness is essential to cope up with pandemic. ${ }^{40,41}$

Majority of the public is aware about common facts related to COVID-19 but still there is anxiety and fear among people. Anxiety is a normal reaction to uncertainty and an uncertainty is till associated with COVID-19. Facts may minimize the anxiety and fears. ${ }^{42}$

The current management is to reduce the virus spread utilizing nonpharmacological intervention and provide supportive care for diseased patients. $^{43}$

There is evidence of asymptomatic transmission too. ${ }^{12,13}$

\section{CONCLUSION}

We got to know so many facts within short period of six months and success stories too and the situation has continuously been unfolding every moment teaching lesson to us. But still lot of information and evidences are required with regard to pharmacological interventions to mitigate the impact of COVID-19 pandemic. We have to live with COVID-19 as the virus is going to stay long; let us continue to practice effective non-pharmacological interventions as to minimize spread of COVID-19 and adequate provision of PPE and testing of health-care workers (HCWs) as to alleviate the anxiety of HCW and lessen their depletion by

\section{REFERENCES}

1. World Health Organization. Novel Coronavirus (2019-nCoV). Situation report-1 (21 January 2020). Available at https://www.who.int/docs/ default-source/coronaviruse/situation-reports/20200121-sitrep-12019-ncov.pdf?sfvrsn=20a99c10_4. Accessed on April 22, 2020.

2. WHO Director-General's opening remarks at the media briefing on COVID-19 - 11 March 2020. Available at https://www.who.int/dg/ speeches/detail/who-director-general-s-opening-remarks-at-themedia-briefing-on-covid-19---11-march-2020. Accessed on April 22, 2020

3. COVID-19 coronavirus pandemic https://www.worldometers.info/ coronavirus/. Accessed on July 01, 2020.

4. Rocklöv J, Sjödin H. High population densities catalyze the spread of COVID-19 [published online ahead of print, 2020 Mar 29]. J Travel Med. 2020; taaa038. doi:10.1093/jtm/taaa038. https://www.ncbi. nlm.nih.gov/pmc/articles/PMC7184409/pdf/taaa038.pdf

5. Read JM, Bridgen JRE, Cummings DAT, Ho A, Jewell CP. Novel coronavirus 2019-nCoV: early estimation of epidemiological parameters and epidemic prediction. med Rxiv. Jan 23, 2020. doi: https://doi.org/10.1101/2020.01.23.20018549 https://www. medrxiv.org/content/10.1101/2020.01.23.20018549v2.full.pdf

6. Early Transmissibility Assessment of a Novel Coronavirus in Wuhan, China - Maimuna Majumder and Kenneth D. Mandl, Harvard University - Computational Health Informatics Program - Posted: 24 Jan 2020 Last revised: 2 https://papers.ssrn.com/sol3/papers. cfm?abstract_id=3524675

7. Report 3: Transmissibility of 2019-nCoV - 25 January 2020 - Imperial College London. https://www.imperial.ac.uk/media/imperialcollege/medicine/sph/ide/gida-fellowships/Imperial-CollegeCOVID19-transmissibility-25-01-2020.pdf

\section{Box 2. What is yet to know}

When this pandemic will end?

Will definitely be the second wave? If there will be second wave, what will be the gravity of second wave in different countries?

Are we prepared to contain second wave?

When will herd immunity develop naturally or with vaccine? (Herd immunity without vaccine is not a preventive measure, waiting for herd immunity to develop naturally could be catastrophic)

When will be effective and safe vaccine available? Whether available vaccine will provide short term immunity or long-lasting immunity? When will vaccine be used for mass vaccination?

Are antibodies developing in patients' serum protective or not?

Will there be reinfection, relapse or reactivation of disease? If there will be what will be the presentation and severity?

When will efficacious and safe drug or drugs will be available for the treatment? Will single drug be sufficient or combination of drugs required? Will drug for chemoprophylaxis be available?

When will be more sensitive test than RT-PCR equally specific to RTPCR developed? When will such test be widely available?

What will be health status of those who recover from critical illness.

There are lot of other queries require explanations.

unnecessary quarantine thereby protecting their health and ultimately reducing hospital transmission. We may continue testing for diagnosis purpose and isolate the patients and trace the contacts and quarantine them as a public health measure to limit the transmission.

8. Statement on the meeting of International Health Regulation (2005) Emergency Committee regarding the outbreak of novel coronavirus (2019-nCoV)-WHO January 23, 2020. https://www.who. int/news-room/detail/23-01-2020-statement-on-the-meeting-ofthe-international-health-regulations-(2005)-emergency-committeeregarding-the-outbreak-of-novel-coronavirus-(2019-ncov)

9. Chen Want et al. A novel coronavirus outbreak of global health concern. The Lancet. Feb 15, 2020; 395: 470-73 https://www.ncbi. nlm.nih.gov/pmc/articles/PMC7135038/pdf/main.pdf

10. WHO Director-General's opening remarks at the media briefing on VOVID-19-3 March 2020. World Health Organization, March 3, 2020.

11. Bill Gates. Responding to COVID-19 - A Once-in-a-Century Pandemic. N Eng J Med. Apr 30 2020; 382 (18): 1677-1679 https://www.nejm. org/doi/pdf/10.1056/NEJMp2003762?articleTools=true

12. Gandhi M, Yokoe D S, Havlir D V. Asymptomatic Transmission, the Achilles' Heel of Current Strategies to Control Covid-19. N Eng J Med. 2020 Apr 24. doi: 10.1056/NEJMe2009758 https://www.nejm.org/ doi/pdf/10.1056/NEJMe2009758?articleTools=true

13. Mary Van Beusekom | News Writer | CIDRAP News | Apr 27, 2020 Study: Many asymptomatic COVID-19 cases undetected. Available at https://www.cidrap.umn.edu/news-perspective/2020/04/studymany-asymptomatic-covid-19-cases-undetected. Accessed on May 01, 2020.

14. World Health Organization. Naming the coronavirus disease (COVID-19) and the virus that causes it. World Health Organization. 2020. Available at: https://www.who.int/emergencies/diseases/ novel-coronavirus-2019/technical-guidance/naming-thecoronavirus-disease-(covid-2019)-and-the-virus-that-causes-it Accessed on May 3, 2020 
15. K. Yuki, Fujiogi M, Koutsogiannaki S. COVID-19 pathophysiology: A review. Clinical Immunology. 2020; 108427. https://doi.org/10.1016/j. clim.2020.108427 https://www.ncbi.nlm.nih.gov/pmc/articles/ PMC7169933/pdf/main.pdf

16. Yang, Xiaobo et al. Clinical course and outcomes of critically ill patients with SARS-CoV-2 pneumonia in Wuhan, China: a singlecentered, retrospective, observational study. The Lancet Respiratory Medicine, 2020. DOI:https://doi.org/10.1016/S2213-2600(20)300795 DOI PubMed GoogleScholar PDF Weblink

17. Heneghan C, Brassey J, Jefferson J. COVID-19: What proportion are asymptomatic? Available at: https://www.cebm.net/covid-19/covid19-what-proportion-are-asymptomatic/ Accessed on May 3, 2020

18. Day M. Covid-19: four fifths of cases are asymptomatic, China figures indicate. BMJ. 2020; 369 doi: https://doi.org/10.1136/bmj.m1375 https://www.bmj.com/content/bmj/369/bmj.m1375.full.pdf

19. Black, James R M et al. COVID-19: the case for health-care worker screening to prevent hospital transmission. The Lancet, May 2, 2020, 395 (10234): 1418 - 1420 https://www.thelancet.com/action/ showPdf?pii=S0140-6736\%2820\%2930917-X

20. World Health Organization. Practical considerations and recommendations for religious leaders and faith-based communities in the context of COVID-19: Interim guidance. Available at: https:// www.who.int/publications-detail/practical-considerationsand-recommendations-for-religious-leaders-and-faith-basedcommunities-in-the-context-of-covid-19 (Accessed on May 3, 2020).

21. National Institutes of Health. Coronavirus Disease 2019 (COVID-19) Treatment Guidelines. https://covid 19 treatmentguidelines.nih.gov/ Accessed on April 22, 2020). DOI PubMed GoogleScholar PDF Weblink

22. Coronavirus disease 2019 (COVID-19) pandemic: increased transmission in the EU/EEA and the UK - seventh update, 25 March 2020. Stockholm: ECDC; 2020. https://www.ecdc.europa.eu/ sites/default/files/documents/RRA-seventh-update-Outbreak-ofcoronavirus-disease-COVID-19.pdf (Accessed on May 3, 2020).

23. World Health Organization.Oxygen sources and distribution for the COVID-19 treatment centers.: Interim guidance 4 April 2020. Available at: https://www.who.int/ publications-detail/ oxygen-sources-anddistribution-for-covid-19-treatment-centres Accessed on May 3, 2020

24. Ventilators Aren't Going to Cure COVID-19. Here's What They Can Do. by Caroline Chen April 15, 2020 Available at: https://www.propublica. org/article/ventilators-arent-going-to-cure-covid-19-heres-whatthey-can-do (Accessed May3, 2020).

25. Higher Mortality Rate in Ventilated COVID-19 Patients in Large Sample - Medscape - Apr 13, 2020. (Accessed May3, 2020). https:// www.medscape.com/viewarticle/928605

26. Black, James $\mathrm{R} M$ et al. COVID-19: the case for health-care worker screening to prevent hospital transmission. The Lancet. May 2, 2020, 395 (10234): 1418 - 20 https://www.ncbi.nlm.nih.gov/pmc/articles/ PMC7162624/pdf/main.pdf

27. Wang D, Hu B, Chang H, et al. Clinical characteristics of 138 hospitalized patients with 2019 novel coronavirus-infected pneumonia in Wuhan, China. JAMA. 2020; 323: 1061-69. https://www.ncbi.nlm.nih.gov/ pmc/articles/PMC7042881/

28. BBC. Coronavirus: 'half of A \& E team' test positive. April 12, 2020. https://www.bbc.co. uk/news/uk-wales-52263285 (Accessed May3, 2020).

29. Tang $Y$, Schmitz J E, Persing D H, Stratton C W. The Laboratory Diagnosis of COVID-19 Infection: Current Issues and Challenges. J. Clin. Microbiol. 3 April 2020 doi:10.1128/JCM.00512-20 https://jcm. asm.org/content/jcm/early/2020/04/03/JCM.00512-20.full.pdf
30. J. Zhang et al., Changes in contact patterns shape the dynamics of the COVID-19 outbreak in China Science 29 April 2020 10.1126/ science. abb8001. https://science.sciencemag.org/content/sci/ early/2020/05/04/science.abb8001.full.pdf

31. deFigueiredo A $M$, Codina $A D$, Marculino de Figueiredo $D C M$, Saez M, Leon AC. Impact of lockdown on COVID-19 incidence and mortality in China: an interrupted time series study. April $20 \mathrm{DOI}$ : 10.2471/BLT.20.256701 https://www.who.int/bulletin/online_ first/20-256701.pdf

32. Eli Klein et. Al. COVID-19 in India: Potential Impact of the Lockdown and Other Longer-Term Policies-CDDEP. Available at: https://cddep. org/wp-content/uploads/2020/04/India-Shutdown-Modeling-SlidesFinal-2.pdf. Accessed on May 3, 2020

33. Lockdown eases (slightly), but up to $7 \mathrm{~m}$ may lose jobs Lockdown eases (slightly), but up to $7 \mathrm{~m}$ may lose jobs Katharine Child. 01 May, 2020 Available at: https://www.businesslive.co.za/fm/features/2020-0501-lockdown-eases-slightly-but-up-to-7m-may-lose-jobs/ Accessed on May 3, 2020

34. Bernd Sebastian Kamps Christian Hoffmann COVID Reference Third Edition 2020 3 Uploaded on 30 April 2020. www.Covid Reference. com Available at: https://amedeo.com/CovidReference03.pdf Accessed on May 3, 2020

35. World Health Organization. "Solidarity" clinical trial for COVID-19 treatments. Available at: https://www.who.int/emergencies/ diseases/novel-coronavirus-2019/ global-research-on-novelcoronavirus-2019-ncov/ solidarity-clinical-trial-for- covid-19treatments. Accessed on May 3, 2020

36. Treatment of Critically III Patients With COVID-19 With Convalescent Plasma. JAMA. 27 March 2020;323(16):1582-1589. doi:10.1001/ jama.2020.4783 https://jamanetwork.com/journals/jama/ fullarticle/2763983

37. WHO landscape documents COVID-19 vaccines- 11 April 2020. Available at: https://www.who.int/blueprint/priority-diseases/keyaction/Novel Coronavirus Landscape nCoV_11April2020.PDF?ua=1 Accessed on May 3, 2020

38. 70 Coronavirus Vaccines Are Under Development, with 3 in Human Trials, WHO Says. https://time.com/5819887/coronavirus-vaccinesdevelopment-who/ Accessed on May 3, 2020

39. Flattening the Covid-19 Peak: Containment and Mitigation Policies. OECD Updated 24 March 2020. Available at: https://read.oecdilibrary.org/view/?ref=124_124999-yt5ggxirhc\&title=Flattening_the _ COVID-19 peak-Containment_and mitigation policies Accessed on May 3, 2020

40. Health care workers face a mental health crisis as they battle the coronavirus pandemic- CNN Opinion by Dr. Shahdabul Faraz. April 4 , 2020. Available at: https://edition.cnn.com/2020/04/04/opinions/ mental-health-crisis-coronavirus-faraz/index.html Accessed on May 3,2020

41. Bansal et al. Clinician Wellness During the COVID-19 Pandemic: Extraordinary Times and Unusual Challenges for the Allergist/ Immunologist. J Allergy Clin Immunol Pract. $2020 \mathrm{https}: / /$ doi. org/10.1016/j.jaip.2020.04.001 https://reader.elsevier.com/reader/ sd/pii/S2213219820303275?token

42. D. Roy, et al. Study of knowledge, attitude, anxiety \& perceived mental healthcare need in Indian population during COVID-19 pandemic. Asian Journal of Psychiatry. 2020; $51.102083 \mathrm{https}: / / \mathrm{doi}$. org/10.1016/j.ajp.2020.102083 https://www.ncbi.nlm.nih.gov/pmc/ articles/PMC7139237/pdf/main.pdf

43. K. Yuki, Fujiogi M, Koutsogiannaki S. COVID-19 pathophysiology: A review. Clinical Immunology. 2020; 108427. https://doi.org/10.1016/j. clim.2020.108427 https://www.ncbi.nlm.nih.gov/pmc/articles/ PMC7169933/pdf/main.pdf 